\title{
Hubungan keterampilan berpikir kritis (metakognitif) dengan indeks prestasi kumulatif pada mahasiswa fakultas kedokteran
}

\author{
Iqbal Raka Aditya Chandra ${ }^{1}$ Purnamawati Tjhin ${ }^{2}$
}

\begin{abstract}
ABSTRAK
\section{LATAR BELAKANG}

Indeks prestasi kumulatif (IPK) adalah hasil pembelajaran atau penilaian capaian pembelajaran mahasiswa pada sebuah program studi. IPK digunakan sebagai sebuah parameter kemajuan proses pendidikan mahasiswa. Banyak faktor yang dapat memengaruhi IPK mahasiswa seperti metakognisi, karakteristik responden, durasi belajar, dan motivasi dalam memperoleh IPK tinggi. Tujuan dari penelitian ini adalah untuk mengetahui hubungan antara keterampilan berpikir kritis (metacognitive), usia dan tingkat perkuliahan dengan IPK pada mahasiswa fakultas kedokteran.
\end{abstract}

\section{METODE}

Penelitian menggunakan desain potong lintang pada 222 responden di Fakultas Kedokteran Universitas Trisakti pada bulan Maret 2018. Pengukuran keterampilan metakognitif menggunakan kuesioner Metacognitive Awareness Inventory (MAI) dan data IPK didapatkan dari data sekunder. Analisis data dilakukan dengan uji Chi square.

\section{HASIL}

Sebagian besar responden berusia 19-20 tahun (56.3\%) yang terbagi menjadi mahasiswa tingkat 1,2 , dan 3 masing-masing sebanyak 74 responden $(33.3 \%)$. Responden memiliki kemampuan metakognitif development (20.7\%), Ok (67.6\%) dan Super (11.7\%). IPK responden terbagi menjadi memuakan (36\%), sangat memuaskan (41.4\%) dan dengan pujian $(22.5 \%)$. Analisis hubungan IPK dengan kemampuan metakognitif $(\mathrm{p}=0.000)$, usia $(\mathrm{p}=0.443)$ dan tingkat perkuliahan $(\mathrm{p}=0.200)$.

\section{KESIMPULAN}

Pada studi ini terdapat hubungan yang bermakna antara keterampilan berpikir kritis (metacognitive) dengan indeks prestasi kumulatif, tetapi antara karakteristik responden (usia, tingkat perkuliahan) tidak berhubungan dengan indeks prestasi kumulatif.

Kata kunci : metakognitif, ipk, usia, tingkat perkuliahan

\author{
${ }^{1}$ Program Studi Kedokteran, \\ Fakultas Kedokteran, \\ Universitas Trisakti \\ 2 Departemen Anatomi, \\ Fakultas Kedokteran, \\ Universitas Trisakti
}

\section{Korespondensi:}

Purnamawati Tjhin

Departemen Anatomi,

Fakultas Kedokteran,

Universitas Trisakti,

Jalan Kyai Tapa No. 260, Grogol,

Jakarta Barat

Email: purnamawati@trisakti.ac.id

J Biomedika Kesehat 2019;2(2):51-57 DOI: 10.18051/JBiomedKes.2019.

v2.51-57

pISSN: 2621-539X / eISSN: 2621-5470

Artikel akses terbuka (open access) ini didistribusikan di bawah lisensi Creative Commons Attribution 4.0 International (CC-BY 4.0) 


\section{ABSTRACT}

\section{Relationship between critical thinking skills (metacognitive) and grade point average in medical students}

\section{BACKGROUND}

The grade point average (GPA) is the result of learning or assessment of student achievement in a study program. GPA is used as a parameter of the progress of the student education process. Many factors can affect student's GPA such as metacognition, respondent's characteristic, duration of study, and motivation in obtaining high GPA. The purpose of this study was to determine the relationship between critical thinking skills (metacognitive), age and academic year with GPA in medical faculty students.

\section{METHODS}

This study is using cross sectional study on 222 respondents of Faculty of Medicine in Trisakti University in march 2018. Metacognitive skill measurement using questionnaire Metacognitive Awareness Inventory (MAI) and GPA data obtained from secondary data. Data analysis was performed by Chi square test.

\section{RESULT}

The majority of respondents aged 19-20 years (56.3\%) divided into students of year 1st, 2nd and 3rd with each students were 74 respondents (33.3\%). Respondents had development metacognitive skill $(20.7 \%)$, Ok (67.6\%) and Super $(11.7 \%)$. Respondent's GPA divided into satisfactory (36\%), very satisfactory $(41.4 \%)$ and with praise $(22.5 \%)$. Analysis of relationship between GPA with metacognitive skill $(\mathrm{p}=0.000)$, age $(\mathrm{p}=0.443)$ and academic year $(\mathrm{p}=0.200)$.

\section{CONCLUSION}

In this study, there is a significant relationship between critical thinking skills (metacognitive) and GPA, the other hand there is norelationship between respondent's characteristic (age, academic year) with GPA.

Keywords : metacognitive, GPA, age, academic year

\section{PENDAHULUAN}

Pada proses pendidikan tinggi, prestasi mahasiswa dapat dinilai dari hasil penilaian terhadap capaian pembelajaran yang telah ditatapkan pada suatu program studi. ${ }^{(1)}$ Proses penilaian pada program studi merupakan suatu proses penilaian yang komprehensif, meliputi penilaian terhadap pengetahuan, keterampilan dan afektif. Oleh karena itu, hasil penilaian yang dalam hal ini IPK dapat digunakan sebagai sebuah parameter kemajuan proses pendidikan mahasiswa. Hasil evaluasi atas kemampuan mahasiswa tersebut pada 1 (satu semester) disebut sebagai indeks prestasi (IP). IP yang diperoleh selama masa studi yang telah ditempuh disebut dengan IP kumulatif (IPK). Secara nasional, penggolongan suatu IP atau IPK untuk program studi Sarjana dikategorikan menjadi memuaskan (IP 2.76-3.00), sangat memuaskan (IP 3.01-3.50) dan dengan pujian (IP > 3.50). ( $^{(2)}$

Pada tahun ajaran 2015/2016 lulusan sarjana kedokteran (S1) Fakultas Kedokteran Universitas Trisakti memperoleh rata-rata IPK sebesar 2.98 (kategori sangat memuaskan) dan meningkat pada tahun ajaran 2016/2017 dengan rata-rata IPK 3.02. IPK tersebut terdistribusi menjadi $33.84 \%$ dengan kategori memuaskan, $59.32 \%$ sangat memuaskan, dan dengan pujian hanya sekitar $6.84 \%{ }^{(3)}$

Banyak faktor yang dapat memengaruhi IPK mahasiswa antara lain metakognitif (berpikir kritis), karakteristik responden, durasi belajar, motivasi dalam memperoleh IPK tinggi yang memiliki signifikansi hubungan yang berbedabeda. ${ }^{(4,5)}$

Secara umum, keterampilan metakognitif terdiri dari 4, yaitu decision making, critical thinking, creative thinking, problem solving. ${ }^{(6)}$ Keempat keterampilan tersebut secara sederhana, dapat dibagi menjadi 2 komponen yang saling berhubungan, yaitu pengetahuan metakognitif dan regulasi metakognitif. ${ }^{(7)}$ Penguasaan terhadap keterampilan metakognitif dapat membantu mengembangkan kemampuan berpikir yang akan berpengaruh terhadap hasil belajar dan membuat mahasiswa akan berprestasi secara akademik. ${ }^{(7)}$

Beberapa penelitian di dalam dan luar negeri menyatakan bahwa terdapat korelasi positif antara keterampilan berpikir kritis dengan prestasi akademik atau pencapaian learning outcomes, namun sebagian menyatakan tidak terdapat korelasi diantara keduanya. ${ }^{(5,8)}$ Penelitian Saemah Rahman dan John Arul Phillips yang dilakukan di Universitas Kebangsaan Malaysia menyatakan terdapat hubungan positif antara berpikir kritis (metacognitive) dengan pencapaian akademik, ${ }^{(5)}$ 
sedangkan menurut penelitian yang dilakukan oleh Kurniawati R dan Leonardi $\mathrm{T}$ yang dilakukan di Universitas Airlangga menyatakan bahwa tidak terdapatnya hubungan antara metakognisi dengan prestasi akademik pada mahasiswa. ${ }^{(8)}$

Pentingnya keterampilan berpikir kritis bagi seorang dokter dan masih adanya perbedaan pendapat tentang hubungan antara kemampuan berpikir kritis dengan prestasiakademik mahasiswa kedokteran, maka peneliti tertarik melakukan penelitian tentang hubungan keterampilan berpikir kritis (metacognitive) dan karakteristik responden (usia dan tingkat perkuliahan) dengan IPK mahasiswa fakultas kedokteran.

\section{METODE}

Penelitian menggunakan desain potong lintang pada 222 mahasiswa Fakultas Kedokteran Universitas Trisakti angkatan 2015, 2016, dan 2017 pada bulan Februari - Mei 2018. Pemilihan sampel dilakukan dengan teknik proportionate stratified random sampling sehingga diperoleh jumlah sampel yang sama untuk ketiga angkatan yaitu sebanyak 74 responden.

Pengumpulan data keterampilan berpikir kritis (metacognitive) dilakukan dengan menggunakan kuesioner metacognitive awareness inventory (MAI) yang telah divalidasi dan disesuaikan dalam konteks pendidikan kedokteran oleh Abdullah R. Kuesioner MAI terdiri dari 51 pertanyaan yang mengukur aspek pengetahuan tentang kognisi (pengetahuan deklaratif, pengetahuan prosedural, pengetahuan kondisional) dan pengendalian atau pengaturan kognisi (perencanaan, manajemen pengelolaan informasi, pemantauan pemahaman, strategi koreksi, evaluasi). Terdapat 4 alternatif pilihan jawaban pada kuesioner MAI yaitu sangat tidak setuju (STS) skor 1, tidak setuju (TS) skor 2, setuju (S) skor 3 dan sangat setuju (SS) skor 4. Jumlah skor yang diperoleh kemudian dikonversikan ke dalam skala 0-100. Pengkategorian tingkat keterampilan metakognisi dilakukan dengan menggunakan rating scale meliputi 6 kategori yaitu super (85-100), ok (68-84), development (51-67), can not really (34-50), risk (17-33), dan not yet $(0-16) .{ }^{(9)}$

Data IPK diperoleh dari data sekunder berupa transkrip nilai mahasiswa semester ganjil 2017/2018. Data IPK digolongkan menjadi
3 kategori, yaitu memuaskan (IP 2.76-3.00), kategori sangat memuaskan (IP 3.01-3.50) dan dengan pujian (IP > 3.50). ${ }^{(1,3)}$

Analisis bivariat data hubungan antara keterampilan berpikir kritis (metacognitive) dan IPK dilakukan dengan uji Chi-square. Penelitian ini sudah mendapatkan persetujuan kaji etik dari FK Trisakti dengan no 42/KER-FK/I/2018.

\section{HASIL}

Pada Tabel 1 dapat dilihat bahwa sebanyak 222 responden yang diteliti berkisar antara 17-22 tahun, dengan sampel terbesar pada usia 19-20 tahun (56.3\%). Masing-masing tingkat perkuliahan terbagi rata $(33.3 \%)$ sehingga tidak ada perbedaan jumlah sampel berdasarkan tingkat perkuliahan.

Ditinjau dari keterampilan metakognitif, sebanyak $67.6 \%$ responden memiliki kemampuan metakognitif ok (skor metakognitif 68-84), 20.7\% responden termasuk kategori metakognitif development (skor metakognitif 51-67) dan 11.7\% responden dengan kategori metakognitif super (skor metakognitif 85-100).

Tabel 1. Karakteristik responden

\begin{tabular}{ll}
\hline Variabel & $\begin{array}{l}\text { Jumlah } \\
(\mathbf{n = 2 2 2})\end{array}$ \\
\hline Metakognitif & \\
Super & 26 \\
Ok & 150 \\
Development & 46 \\
Indeks Prestasi Kumulatif (IPK) & \\
Memuaskan & 80 \\
Sangat Memuaskan & 92 \\
Pujian & 50 \\
Usia & \\
17-18 tahun & 45 \\
19-20 tahun & 125 \\
21-22 tahun & 52 \\
Tingkat Perkuliahan & \\
Tingkat 1 & 74 \\
Tingkat 2 & 74 \\
Tingkat 3 & 74 \\
\hline
\end{tabular}

Ditinjau dari pencapaian prestasi akademik didapatkan sebanyak $63.9 \%$ responden memiliki prestasi yang tinggi meliputi IPK dengan kategori sangat memuaskan sebanyak $41.4 \%$ dan memiliki kategori dengan pujian sebanyak $22.5 \%$. Hasil uji Chi-square analisis hubungan antara keterampilan metakognitif dan indeks prestasi kumulatif pada mahasiswa fakultas kedokteran pada Tabel 2 menunjukkan terdapat hubungan yang bermakna antara keterampilan berpikir kritis 
Tabel 2. Hubungan keterampilan berpikir kritis (metakognitif) dengan indeks prestasi kumulatif pada mahasiswa fakultas kedokteran

\begin{tabular}{|c|c|c|c|c|c|c|c|}
\hline \multirow{3}{*}{ Variabel } & \multicolumn{6}{|c|}{ Indeks Prestasi Kumulatif } & \multirow{3}{*}{ p-value* } \\
\hline & \multicolumn{2}{|c|}{ Memuaskan } & \multicolumn{2}{|c|}{$\begin{array}{c}\text { Sangat } \\
\text { Memuaskan }\end{array}$} & \multicolumn{2}{|c|}{ Pujian } & \\
\hline & $\mathbf{n}$ & $\%$ & $\mathbf{n}$ & $\%$ & $\mathbf{n}$ & $\%$ & \\
\hline \multicolumn{8}{|l|}{ Metakognitif } \\
\hline Super & 3 & $11.5 \%$ & 14 & $53.8 \%$ & 9 & $34.6 \%$ & \\
\hline $\mathrm{Ok}$ & 35 & $23.3 \%$ & 75 & $50 \%$ & 40 & $26.7 \%$ & $0.000 \phi^{*}$ \\
\hline Development & 42 & $91.3 \%$ & 3 & $6.5 \%$ & 1 & $2.2 \%$ & \\
\hline
\end{tabular}

Keterangan: $\mathrm{n}=$ frekuensi; $\%=$ persentase $; \phi=$ Chi square test;

$*=\mathrm{p}<0.05$, perbedaan bermakna

(metacognitive) dan indeks prestasi kumulatif pada mahasiswa fakultas kedokteran $(\mathrm{p}=0.000)$.

Mahasiswa yang memiliki keterampilan metakognitif super sebagian besar memiliki IPK memuaskan (53\%) dan dengan pujian (34.6\%). Sedangkan mahasiswa dengan metakognitif kategori development mayoritas memiliki IPK memuaskan (91.3\%) dan hanya $6.5 \%$ yang memiliki IPK sangat memuaskan dan $2.2 \%$ yang memiliki IPK dengan pujian. Hasil ini dapat lebih mudah dilihat pada Gambar 1 antara keterampilan berpikir (metakognitif) dengan IPK mahasiswa kedokteran.

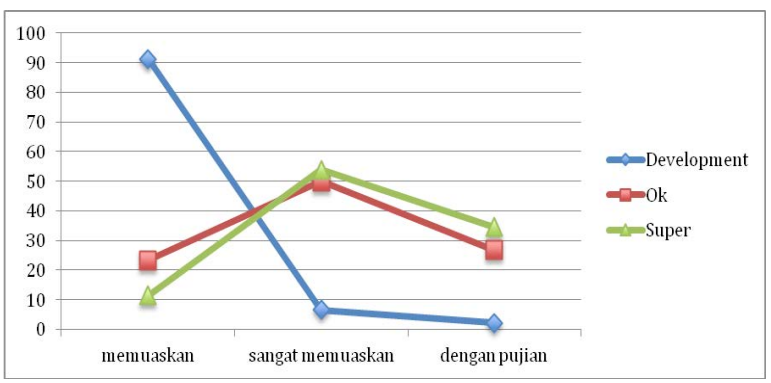

Gambar 1. Hubungan antara keterampilan berpikir (metakognitif) dengan IPK mahasiswa kedokteran

Hasil analisis hubungan antara karakteristik responden (usia, tingkat perkuliahan) dan indeks prestasi kumulatif pada Tabel 3 menunjukkan tidak terdapat hubungan yang bermakna antara karakteristik responden baik usia $(\mathrm{p}=0.443)$ maupun tingkat perkuliahan $(\mathrm{p}=0.200)$ dengan dan indeks prestasi kumulatif mahasiswa fakultas kedokteran. Responden pada semua rentang usia dan semua tingkat kuliah memiliki IPK yang sebagian besar pada kategori sangat memuaskan. Responden tingkat kuliah 3 lebih banyak yang memiliki IPK dengan pujian dibandingkan dengan responden tingkat 2 dan tingkat 1 .

\section{PEMBAHASAN}

Paul R menyatakan bahwa berpikir kritis atau metakognitif merupakan suatu disiplin ilmu dan merupakan suatu self-directed thinking yang menunjukkan kesempurnaan pemikiran yang sesuai untuk suatu domain tertentu. Berpikir kritis merupakan berpikir yang menunjukkan penguasaan keterampilan dan kemampuan intelektual sehingga membuat pemikirannya lebih baik, menjadi lebih jelas, lebih akurat dan lebih dapat dipertahankan. ${ }^{(10)}$ Dengan kata lain, metakognitif adalah berpikir tentang berpikir dan mengacu pada pengendalian kognisi dengan

Tabel 3. Hubungan karakteristik responden (usia, tingkat perkuliahan) dengan indeks prestasi kumulatif pada mahasiswa fakultas kedokteran

\begin{tabular}{|c|c|c|c|c|c|c|c|}
\hline \multirow{3}{*}{ Variabel } & \multicolumn{6}{|c|}{ Indeks Prestasi Kumulatif } & \multirow{3}{*}{ p-value* } \\
\hline & \multicolumn{2}{|c|}{ Memuaskan } & \multicolumn{2}{|c|}{$\begin{array}{c}\text { Sangat } \\
\text { Memuaskan }\end{array}$} & \multicolumn{2}{|c|}{ Pujian } & \\
\hline & $n$ & $\%$ & $\mathbf{n}$ & $\%$ & $\mathbf{n}$ & $\%$ & \\
\hline Usia & & & & & & & \multirow{4}{*}{$0.443 \phi$} \\
\hline 17-18 tahun & 14 & $31.1 \%$ & 18 & $40 \%$ & 13 & $28.9 \%$ & \\
\hline 19-20 tahun & 51 & $40.8 \%$ & 49 & $39.2 \%$ & 25 & $20 \%$ & \\
\hline 21-22 tahun & 15 & $28.8 \%$ & 25 & $48.1 \%$ & 12 & $23.1 \%$ & \\
\hline \multicolumn{8}{|l|}{ Tingkat Perkuliahan } \\
\hline Tingkat 1 & 33 & $44.6 \%$ & 27 & $36.5 \%$ & 14 & $18.9 \%$ & \multirow{3}{*}{$0.200 \phi$} \\
\hline Tingkat 2 & 28 & $37.8 \%$ & 29 & $39.2 \%$ & 17 & $23 \%$ & \\
\hline Tingkat 3 & 19 & $25.7 \%$ & 36 & $48.6 \%$ & 19 & $25.7 \%$ & \\
\hline
\end{tabular}

\footnotetext{
Keterangan: $\mathrm{n}=$ frekuensi; $\%=$ persentase; $\phi=$ Chi square test;
}

$*=\mathrm{p}<0.05$, perbedaan bermakna 
benar-benar sadar. ${ }^{(10-12)}$

Konsensus The APA Delphi Report mendefinisikan berpikir kritis sebagai penilaian yang bertujuan dan mendalam yang bermanifestasi dalam pertimbangan terhadap fakta, konteks, metode, standard, dan konsep dalam memutuskan apa yang akan dipercaya dan apa yang akan dilakukan. $^{(13)}$

Keterampilan metakognitif merupakan keterampilan berpikir tingkat tinggi sehingga berkaitan dengan tugas dari bagian depan otak atau disebut dengan lobus prefrontal/prefrontal cortex. Belahan otak bagian depan ini dikenal sebagai pusat kontrol eksekutif atau pusat berpikir tingkat tinggi, tempat upaya pemecahan masalah, regulasi dimensi emosi, penentu watak dan karakter dan kepribadian seseorang. ${ }^{(6)}$

Hasil penelitian univariat mengenai kategori keterampilan metakognitif yang dimiliki responden menunjukkan bahwa $11.7 \%$ responden memiliki kemampuan metakognitif super atau sangat baik, $67.6 \%$ memiliki kemampuan metakognitif ok atau baik dan $20.7 \%$ dengan kemampuan metacognitive development atau sedang. Tidak ditemukan kemampuan metakognitif yang lebih rendah daripada development. Hal ini menunjukkan bahwa pada tingkat mahasiswa telah terjadi serangkaian proses pendidikan yang turut membangun keterampilan berpikir kritis sehingga menjadi semakin matang. ${ }^{(14)}$ Selain itu, pertambahan usia menyebabkan semakin meningkat pula kematangan dari fungsi-fungsi fisiologisnya, termasuk fungsi lobus prefrontal yang menjadi pusat berpikir tingkat tinggi. ${ }^{(6,15)}$

Hasil uji Chi square analisis hubungan antara keterampilan metakognitif dan indeks prestasi kumulatif pada mahasiswa fakultas kedokteran pada Tabel 2 menunjukkan terdapat hubungan yang bermakna antara keterampilan berpikir kritis (metacognitive) dan indeks prestasi kumulatif pada mahasiswa fakultas kedokteran $(p=0.000)$. Hasil ini sejalan dengan penelitian yang dilakukan oleh Rahman S, Philips JA, yang dilakukan pada 374 mahasiswa tahun ke-2 di Universitas Kebangsaan Malaysia. Penelitian tersebut menyatakan bahwa kesadaran metakognisi menunjukkan hubungan positif yang signifikan dengan pencapaian akademik. ${ }^{(5)}$ Hasil yang sama juga ditemukan pada penelitian yang dilakukan oleh Young A, Fry JD pada mahasiswa sarjana dan pascasarjana di Texas Tenggara, menyatakan terdapatnya korelasi yang signifikan antara metakognitif dan pencapaian akademik atau IPK. ${ }^{(7)}$

Terdapatnya hubungan yang bermakna antara keterampilan metakognitif dengan prestasi mahasiswa dapat dijelaskan karena keterampilan metakognitif mencakup beberapa aspek pengetahuan tentang kognisi (pengetahuan deklaratif, pengetahuan prosedural, pengetahuan kondisional) dan pengendalian atau pengaturan kognisi (perencanaan, manajemen pengelolaan informasi, pemantauan pemahaman, strategi koreksi, evaluasi). ${ }^{(9)} \quad$ Komponen-komponen inilah yang berperan dalam proses pembelajaran seseorang, sehingga jika komponen metakognisi ini semakin baik maka proses dalam suatu pembelajaran pun akan baik dan menghasilkan output pembelajaran yang baik pula.

Self-questioning merupakan salah satu strategi metakognitif, aktifitas merencanakan bagaimana menyelesaikan suatu tugas yang diterima, memonitor pemahaman dan melakukan evaluasi tugas merupakan metakognitif yang terjadi sehari-hari. ${ }^{(16)}$ Dengan demikian aspek metakognisi (pengetahuan kognisi dan pengaturan kognisi) terus diasah seiring berjalannya proses pembelajaran. Dosen atau teman dapat berperan membantu memberikan evaluasi maupun masukan dalam proses berpikir mahasiswa sehingga terjadi proses evaluasi terhadapapayang telah dikerjakan. Keterampilan berpikir kritis yang terus diperbaiki, digunakan untuk mengatur kognisi dan memaksimalkan potensi berpikir individu serta mengkaji berbagai informasi yang diterima dengan tepat. ${ }^{(17)}$ Semakin baiknya kesadaran mahasiswa mengenai proses berpikirnya saat belajar maka akan semakin baik pula kontrol tujuan, kepribadian serta perhatiannya, dengan demikian akan berdampak pada kemampuan metakognitif mahasiswa tersebut sehingga berpengaruh pada hasil belajarnya. ${ }^{(17)}$

$\begin{array}{ccr}\text { Kemampuan } & \text { berpikir } & \text { kritis } \\ \text { (metacognitive) sangat } & \text { dibutuhkan } & \text { untuk } \\ \text { menyimak, memantau, } & \text { merancang } & \text { dan }\end{array}$
memprediksi, yang semuanya merupakan ciri dari pemikiran yang efisien. Proses pembelajaran aktif akan meregulasi dan memperbaiki hasil tindakan kognitif yang akhirnya akan berpengaruh pula pada hasil pembelajaran. ${ }^{(5,7,16,17)}$ 
Hasil analisis bivariat antara karakteristik responden (usia, tingkat perkuliahan) dan indeks prestasi kumulatif pada mahasiswa Fakultas Kedokteran Universitas Trisakti menunjukkan hasil tidak ada perbedaan bermakna baik dari segi usia $(p=0.443)$ maupun dari segi tingkat perkuliahan $(\mathrm{p}=0.200)$ dengan indeks prestasi kumulatif. Beberapa penelitian sejalan dengan hasil penelitian ini antara lain penelitian yang dilakukan oleh Vallmuur $\mathrm{K}$ di Brisbane dan penelitian oleh Pantages TJ, Creedon $\mathrm{CF}$ di Amerikayang menyatakan bahwa usia bukanlah faktor krusial yang mempengaruhi hasil akademik seseorang. ${ }^{(18,19)}$ Sebaliknya hasil yang berbeda didapatkan pada penelitian yang dilakukan Hakam M, Sudarno, Hoyyi A pada mahasiswa statistika Universitas Diponegoro Semarang memperoleh hasil bahwa usia memiliki pengaruh yang signifikan pada IPK. ${ }^{(15)}$

Inkonsistensi hasil penelitian sebelumnya mengenai hubungan usia dengan prestasi akademik, dapat dijelaskan sebagai berikut: usia dapat memiliki hubungan positif dengan pencapaian akademik karena terkait dengan dengan proses tumbuh kembang yang terus berlangsung seiring pertambahan usia. Semakin bertambah usia, kematangan berbagai fungsi fisiologis akan meningkat. ${ }^{(15)}$ Terdapat perbedaan gaya belajar yang diterapkan sesuai dengan usia mahasiswa. Mahasiswa yang berusia lebih matang, lebih cenderung memproses informasi melalui pengalaman reflektif, sementara mahasiswa berusia lebih muda, lebih cenderung memproses informasi dengan eksperimen aktif. ${ }^{(20)}$ Siswa dengan usia yang matang memiliki persepsi tentang keadaannya sekarang sebagai kesempatan terakhir dalam pengembangan karirnya, dan melihat pendidikan sebagai katalisator untuk membuat perubahan pada hidupnya untuk sukses. $(21,22)$

Selain kematangan fungsi fisiologis dan tumbuh kembang, prestasi akademik sangat tergantung pada berbagai faktor, misalnya prior knowledge, keterampilan berpikir kritis (metacognitive), sikap tahan banting, gaya belajar, motivasi, lingkungan eksternal, lebih memegang peranan dalam menentukan proses pembelajaran yang dilakukan oleh mahasiswa sehingga berpengaruh terhadap pencapaian akademik. ${ }^{(22)}$

\section{KESIMPULAN}

Pada studi ini terdapat hubungan keterampilan berpikir kritis (metacognitive) dengan indeks prestasi kumulatif $(p=0.000)$. Mahasiswa dengan keterampilan berpikir kritis (metacognitive) yang makin baik, memiliki indeks prestasi kumulatif makin tinggi. Di pihak lain, tidak terdapat hubungan bermakna antara usia dan tingkat kuliah dengan indeks prestasi kumulatif pada mahasiswa Fakultas Kedokteran Universitas Trisakti.

\section{UCAPAN TERIMA KASIH}

Terima kasih kepada Dekan Fakultas Kedokteran Universitas Trisakti yang telah memberikan izin pengambilan data penelitian di Fakultas Kedokteran Universitas Trisakti Jakarta dan seluruh sivitas akademika Fakultas Kedokteran Universitas Trisakti khususnya mahasiswa angkatan 2015, 2016, dan 2017 sebagai responden pada penelitian.

\section{KONFLIK KEPENTINGAN}

Penulis tidak memilikikonflik kepentingan dengan diterbitkannya hasil penelitian ini.

\section{KONTRIBUTOR}

Iqbal Raka Aditya Chandra melakukan pengumpulan data, penanggung jawab pengumpulan data di lapangan, persiapan makalah. Purnamawati Tjhin merevisi makalah akhir untuk publikasi. Iqbal Raka Aditya Chandra dan Purnamawati Tjhin menyusun konsep, merancang penelitian, analisa data dan interpretasi data.

\section{DAFTAR REFERENSI}

1. Direktorat Pembelajaran dan Kemahasiswaan DIKTI Kementerian Pendidikan dan Kebudayaan RI. Kerangka Kualifikasi Nasional Indonesia. 2011. Available from :http://www.kopertis3.or.id/ html/wp-content/uploads/2011/12/kompetensidan-learning-outcomes-dikti.pdf.

2. Republik Indonesia. Peraturan Menteri Pendidikan dan Kebudayaan RI Nomor 49 Tahun 2014 tentang Standar Nasional Pendidikan Tinggi Pasal 1 Ayat 7. Sekretariat Negara. Jakarta. 2014.

3. FK Trisakti. Borang Akreditasi Program Studi Kedokteran Universitas Trisakti tentang Mahasiswa dan Alumni. Jakarta. 2016.

4. Fang, Legaspi C, Perez R, Remigio A, Sengsourya J. Factors affecting GPA. Public csusm.edu. 2012. Available from: http://public.csusm.edu/fangfang/ Teaching/BUS304/TeamPresentation-Spr08/ Report Group3.pdf. Accessed October 31, 2017.

5. Rahman S, Philips JA. Hubungan antara Kesedaran Metakognisi, Motivasi dan Pencapaian Akademik 
Pelajar Universiti. J Pendidikan Kebangsaan Malaysia. 2006;31:21-39.

6. Fitri R. Metakognitif pada Proses Belajar Anak dalam Kajian Neurosains. J Pendidikan. 2017;2:44-52. DOI: http://dx.doi.org/10.26740/ jp.v2n1.p56-64

7. Young A, Fry JD. Metacognitive Awareness and Academic Achievement in College Students. J Scholarsh Teach Learn [Internet]. 2008;8(2):110. Available from: http://library3.webster.edu/ login?url=http://search.ebscohost.com/login.aspx ?direct $=$ true $\& \mathrm{db}=$ eric $\& \mathrm{AN}=\mathrm{EJ} 854832 \&$ site $=\mathrm{eho}$ st-live.Accessed November 21, 2017.

8. Kurniawati R, Leonardi T. Hubungan Antara Metakognisi dengan Prestasi Akademik pada Mahasiswa Fakultas Psikologi Universitas Airlangga yang Aktif Berorganisasi di Organisasi Mahasiswa Tingkat Fakultas. J Psikologi Pendidikan dan Perkembangan. 2013;2(1):1-6.

9. Abdullah R. Validasi Instrumen Penilaian Metakognisi (metacognitive awareness inventory) dalam konteks pendidikan dokter tahap akademik. 2015. Available from: http:// perpustakaan.fk.ui.ac.id/opac/index.php? $\mathrm{p}=$ show detail\&id $=23028 \& \mathrm{keywords}=$. Accesse $\overline{\mathrm{d}}$ November 23, 2017.

10. Paul RW. Elder L. Critical Thinking. Prentice Hall. New Jersey: 2002. pg. 7-15.

11. Lai ER. Metacognition: A Literature Review. Research Report. Pearson; 2011.

12. Romli M. Strategi Membangun Metakognisi Siswa SMA dalam Pemecahan Masalah Matematika. eJournal IKIP Madura. 2012. Available from: http://ejournal.ikippgrismg.ac.id/index.php/ aksioma/article/download/56/52.Accessed November 23, 2017.

13. Facione PA. Critical thinking: what it is and why it counts [Internet]. 2017. Available from: http://www.insightassessment.com/pdf files/ what\&why2006.pdf.Accessed October 26, 2017.

14. Kolenic PL, Hillwig SA. Encouraging Metacognition: Supporting Learners Through Metacognitive Teaching Strategies. Peter Lang Publishing. New York; 2011.

15. Hakam M, Sudarno, Hoyyi A. Analisis Jalur Terhadap Faktor-Faktor yang Memengaruhi Indeks Prestasi Kumulatif (IPK) Mahasiswa Statistika UNDIP. J Gaussian. 2015;4(1):61-70.

16. Ardila $\mathrm{C}$, Corebima AD, Zubaidah S. Hubungan Keterampilan Metakognitif Terhadap Hasil Belajar Biologi dan Retensi Siswa Kelas X Dengan Penerapan Strategi Pemberdayaan Berpikir Melalui Pertanyaan (PBMP) Di SMAN 9 Malang [Internet]. Jurusan Biologi FMIPA Universitas Negeri Malang, Malang; 2013;1-9. Available from: https://bit.ly/2XR7pIK. Accessed November 21, 2017.

17. Romli M. Strategi Membangun Metakognisi Siswa SMA dalam Pemecahan Masalah Matematika. eJournal IKIP Madura. 2012. Available from: http://ejournal.ikippgrismg.ac.id/index.php/ aksioma/article/download/56/52. Accessed November 23, 2017.

18. McKenzie K, Schweitzer R. Who Succeeds at University? Factors predicting academic performance in first year Australian university students. Higher Education Research \& $\begin{array}{lll}\text { Development. } & \text { 2001. (20):21-33. DOI: }\end{array}$ 10.1080/07924360120043621

19. Pantages TJ, Creedon CF. Studies of College
Attrition: 1950-1975. Review of Educational Research. 1978;49-101. Available from: https:// doi.org/10.3102/00346543048001049

20. Owen R. Retention Implications of a Relationship between Age and GPA [Internet]. College Student Journal. 2003. Available from: https://www. questia.com/library/journal/1G1-103563740/ retention-implications-of-a-relationship-betweenage. Accessed Juli 19, 2018.

21. Sheard M. Hardiness commitment, gender, and age differentiate university academic performance. Br J Educ Psychol. 2009; 79(Pt 1):189-204. doi: 10.1348/000709908X304406.

22. Shanahan M. Being that bit older: Mature students' experience of university and healthcare education. OTI. 2006;(7):153-62.Available from: https://doi. org/10.1002/oti.116 